\title{
Remembering William Thomas Green Morton: The Birth of Anesthesia Between Cultural Amnesia, Myth and History
}

\author{
Giulia Petrini ${ }^{1 *}$ and Armando Fucci ${ }^{2}$ \\ ${ }^{1}$ Department of anesthesia and critical care, AOU Città della Salute e della Scienza di Torino, University of Turin, Italy \\ ${ }^{2}$ Department of anesthesia and critical care, UOC Azienda Ospedaliera Universitaria Senese, Italy
}

Submission: October 30, 2019; Published: November 06, 2019

*Corresponding author: Giulia Petrini, Department of anesthesia and critical care, AOU Città della Salute e della Scienza di Torino, University of Turin, Italy

\section{Abstract}

Two centuries ago, on August $19^{\text {th }}, 1819$ it came to the world a legendary medical personality. William Thomas Green Morton is considered the pioneer of painless surgery. At the time of the discovery he was only 27 years old. The vapor initially used to introduce the world to practical clinical anesthesia was that of ether. Surgical anesthesia and analgesia have become an accepted standard in surgical and medical care.

Keywords: Ether; William Morton; Inhalational anesthesia

\section{Introduction}

Two centuries ago, on August $19^{\text {th }}, 1819$, it came to the world a legendary medical personality. William Thomas Green Morton was born in Charlton, Massachusetts, in an old-fashioned farmhouse at 10 Prenier Rd. Since the time of his early childhood he had had only one wish: to be a physician. He was an American dentist who first publicly demonstrated the use of inhaled ether as a surgical anesthetic. Morton was not the inventor but certainly the "revealer" of inhalational anesthesia [1]. Friday October $16^{\text {th }}$, 1846, the date remembered as Ether Day, marked the watershed between the past agonies of surgery and the modern era. Around ten o' clock Morton publicly administered inhaled ether to a patient at Massachusetts General Hospital. It took place in an amphitheater now known as the "Ether Dome", now being used as a lecture theater. At that time, he was only 27 years old. The patient was successfully anesthetized and the surgeon, Doctor John Warren, removed a tumor from his neck [2]. The vapor initially used to introduce the world to practical clinical anesthesia was that of ether. In Greek mythology, Aether, also known as Acmon, is one of the primordial deities, the first-born elementals. His name means "light" in ancient Greek. Aether is the personification of the bright, glowing upper air of heaven, the substance of light. He is a divine power of the higher and purer sky. He embodies the pure upper air that the gods breathe, as opposed to the normal air breathed by mortals. Aether was known in ancient science as the fifth element, after earth, water, air, and fire: the material that fills up the universe beyond earth, also later known as quintessence [3].

The compound known as diethyl ether had been known for centuries; it may have been synthesized by an eight-century Arabian philosopher Jabir ibn Hayyan, or possibly by Raymond Lully, a thirteen century European alchemist. Lully is most credited with the discovery of ether, as is Paracelsus and his pupil Valerius Cordus. Wilhelm Godefroy Froben, a German chemist, described the preparation of ether and gave the drug its present name in 1735; he changed the name from sweet vitriol to spiritus aetherius. The name derives from a Greek word meaning "to burn brilliantly", which was applied to the zenith, the quintessence of light and thence, by analogy, to the impalpable matter that separates one constellation from another [4]. Descriptions of ether experiences sound like a nineteenth century discussion of luminiferous ether. Luminiferous ether was the hypothetical substance through which electromagnetic waves traveled, it was proposed by a Greek philosopher Aristotle, the skies of Dante's paradise are constituted by a fifth element called by Dante etere, or etra or fifth element, a pure and crystalline element impossible to see. This formula was known as the ether theory. The ether 
theory was proposed by a physician named Thomas Young $[5,6]$. Although the existence of substances that could provide relief from pain had been known for many centuries, those who were ill and in pain usually turned to religion, superstition, astrology and magic. The 18th century enlightenment promoted the idea that human reason could be used to combat ignorance, superstition and tyranny. This led directly to the development of scientific ideas into practical applications. I believe this discovery had to do also with the Salem witch trials.

Ether mimics an intimate connection to distant spaces. It was no accident that this anesthetic was called ether, and the two ethers had more in common than just the name. Both suggested something otherwordly, immeasurable, invisible and experienced imaginatively; both implied a physics of energy consumption and expulsion; and both were characterized by connecting things separated in space [5]. Liquid ether was easily transported in bottles. The concentrations required for surgical anesthesia were low enough that hypoxia was not a problem when breathing ether vaporized in air. Ether additionally had a unique property among all inhaled anesthetics: at levels of surgical anesthesia there was no respiratory depression. These properties when combined with ether's slow uptake provided a significant margin of safety in the hands of relatively unskilled anesthetists [7]. Morton solicited for a patent to ether. Once the patent was conceded, he marketed the anesthetic agent as Letheon, a mixture of ether and oil of orange. The name is adopted from Lethe, the river of forgetfulness, that is one of the five rivers of the Greek underworld. The shades of the dead were required to drink the waters of the Lethe in order to forget their earthly life in order to proceed with reincarnation [8]. The patent \#4848 was officially granted on November 17, 1846, for his method of etherization, which used a glass jar with a rubber tube. Surgeons at MGH insisted on knowing the composition of the agent. By January 1847 it was discovered that tincture of orange and perfumes had been added to ether and Morton's claim to his patent collapsed [9]. Morton kept the true composition of Letheon a secret with the hopes of becoming whealty. The last twenty years of Morton's life, were spent in the perpetual torment of bitter controversy and litigation, as a result he was reduced to poverty. The intensity of Morton's insistence on his priority and his obsession for wealth led to a bitter struggle that was fought in the press, academia, the courts, Congress, and the White House [10].

October 16th is World Anesthesia Day. This ranks as one of the most significant events in the history of medicine. Morton's arrival at the amphitheater had been 15 minutes delayed because he was obliged to wait for an instrument maker to complete a new inhaler. It consisted of a large glass bulb inside of which there was a spong soaked with colored ether with a spout placed in the patient's mouth $[11,12]$. Morton's role in this discovery is much debated by historians. It is clear from history that Dr. William Morton's trial of the use of ether as an anesthetic in the theatre at Massachusetts General Hospital was the first successful administration of modern anesthesia. What is also clear is that he was unlike other doctors and scientists of the age. He was not a scientist, he was a keen observer. He learned about inhalational anesthesia at a failed demonstration by Horace Wells and then sought Thomas Jackson's help as a chemist. Jackson suggested that Morton could improve narcotic inhalational vapors results by using chemically purified sulfuric ether instead of nitrous oxide. In the summer of 1846 he carried out experiments with gold fish, caterpillars, insects, worms. He tried ether on his little spaniel dog, on two of his young dental apprentices and even on himself. His genius resided not only in his observations but also in developing a rough method that could permit safe inhalation. William Morton had dark, wavy hair, intense blue eyes and extravagant moustache. He dressed up extravagantly too. He is described as "as a charlatan, entrepreneur, student of Horace Wells". It does not seem to be generally understood that before ether there was nothing. Before William Morton surgery meant agony [2,10,12-15]. William Morton promoted global health and battled public health disasters. Pain is a scandal. William Morton saved humanity. He battled pain in its multiple natures: physical, phsycological and moral, or else physical and metaphysical.

Figure 1: Captain Ether.

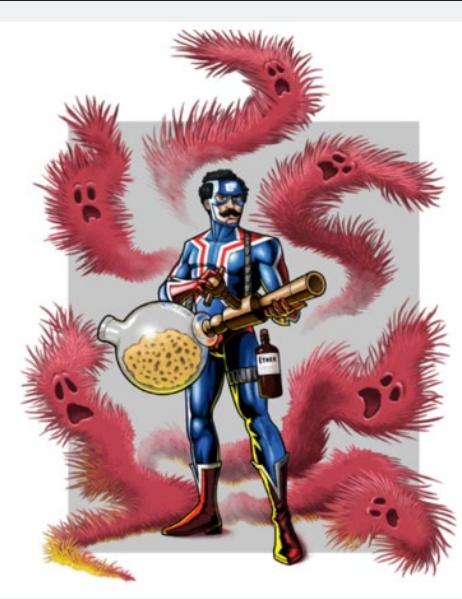


At the Battle of the Wilderness General and later President Ulysses Grant said: "William Morton has done more for the soldier than anyone else, soldier or civilian, for he has taught you all to banish pain." What he reached was a true gift to mankind and what he achieved was accomplished at immense personal cost. I picture Dr Morton as a hero in comics, Captain Ether (Figure 1 ), defeating pain and saving people from the agony of surgery and from those dreadful operations where our patients would feel every nerve severed with each stroke of the knife. Dwarfed the magnitude of his revelation, reviled, hated by his fellow men, forgotten before he was remembered, Morton seems very small indeed until he was immortalized as the founder of painless surgery. The invention of surgical anesthesia was the first major contribution that American medical science made to the world and it is probably still the greatest of America's many medical discoveries. Surgical anesthesia and analgesia have become an accepted standard in medical care. The story of the discovery of inhalational anesthesia sounds like a medical melodrama. It is full of comedy, tragedy and intrigue. It is amusing and it sounds so familiar, one can recognize many aspects of it in the hospital dynamics we witness everyday including the interactions among hospital staff colleagues. Some things don't seem to change.

\section{References}

1. Camosse M, Menard K, Desai MS (2014) Homes associated with William Thomas Green Morton. Bull Anesth Hist 32(1): 1,4-7,15.

2. Fenster JM (2002) Ether Day. New York HarperCollins Publishers Inc.
3. Sarton G (2011) Ancient Science Through the Golden Age of Greece. Dover Publications.

4. Barash PG, Cullen BF, Stoelting RK (2001) Clinical anesthesia. $4^{\text {th }}$ Edn Philadelphia, Pa: London: Lippincott Williams \& Wilkin.

5. Whittaker ET (2008) A history of the theories of aether and electricity: from the age of Descartes to the close of the nineteenth century. Kessinger Publishing.

6. Alighieri D (1997) La divina commedia. Fiesole: Nardini Editore.

7. Chang CY, Goldstein E, Agarwal N, Swan KG (2015) Ether in the developing world: rethinking an abandoned agent. BMC Anesthesiol 15: 149 .

8. Virgilio (2005) Eneide. Milano Giunti Editore.

9. Moore FD (1999) John Collins Warren and his act of conscience: a brief narrative of the trial and triumph of a great surgeon. Ann Surg 229(2): 187-196.

10. Wolfe RJ (2001) Tarnished idol. San Anselmo Norman Publishing.

11. Haridas RP (2009) William TG Morton's early ether inhalers: a tale of three inhalers and their inscriptions. Anaesth Intensive Care 37(1): 30-35.

12. Wolfe RJ, Hinckley RC. Robert C (1993) Hinckley and the recreation of the First Operation under Ether. Boston: the Boston medical library in the Francis A. Countway library of medicine.

13. López-Valverde A, Montero J, Albaladejo A, Gómez de Diego R (2011) The discovery of surgical anesthesia: discrepancies regarding its authorship. J Dent Res 90(1): 31-34.

14. Baker R (1946) Dr Morton, pioneer in the use of ether. New York: Julian Messner.

15. Nuland SB (1983) The origins of anesthesia. The classics of medicine library. Birmingham.

\section{Your next submission with Juniper Publishers will reach you the below assets}

- Quality Editorial service

- Swift Peer Review

- Reprints availability

- E-prints Service

- Manuscript Podcast for convenient understanding

- Global attainment for your research

- Manuscript accessibility in different formats

( Pdf, E-pub, Full Text, Audio)

- Unceasing customer service

Track the below URL for one-step submission https://juniperpublishers.com/online-submission.php 